\title{
EVALUASI EFISIENSI ENERGI PENGERING MULTISILINDER PADA MESIN KERTAS UNTUK PRODUKSI KERTAS TULIS-CETAK GRAMATUR RENDAH
}

\author{
Trismawati \\ Fakultas Teknik Universitas Panca Marga, Pabean Dringu Probolinggo \\ trisma.saja@yahoo.com
}

Diterima : 22 Agustus 2013, Revisi akhir : 28 November 2013, Disetujui terbit : 02 Desember 2013

\begin{abstract}
THE EVALUATION OF MULTICYLINDER DRYER ENERGY EFFICIENCY ON PAPER MACHINE FOR THE PRODUCTION OF PRINTED PAPER WITH LOW GRAMMAGE
\end{abstract}

\begin{abstract}
Paper machine has been designed for special purposes in accordance with the fiber characteristic used as the raw material, fiber development needed, and the fiber network developed so that the incremental water content reduction in the paper web from the inlet point of cylindrical dryer up to the outlet point of cylindrical dryer optimum. In industrial application, the paper machine designed for basis weight 60 gsm and virgin pulp as the raw material is often used for 45 gsm productions with virgin and recycled fiber as the raw material because of the paper demand. In this research the cylindrical dryer performance was observed when used for $45 \mathrm{gsm}$ writing and printing paper production and their ability to dry the paper up to the design speed was simulated. Hopefully the result will able to give a contribution for energy efficiency so that the reduction of contribution margin can be anticipated.
\end{abstract}

Keywords: cylindrical dryer, designed speed, energy efficiency, contribution margin.

\begin{abstract}
ABSTRAK
Mesin kertas telah dirancang sesuai peruntukannya khususnya menyesuaikan dengan karakteristik serat yang digunakan sebagai bahan baku, pengembangan serat yang diinginkan dan jaringan serat yang terbentuk. Hal ini agar pengurangan kadar air yang terjadi secara bertahap dari pengering silinder ujung awal sampai ujung akhir dapat berjalan optimal. Dalam aplikasi industri sering dilakukan penyimpangan seperti mesin kertas yang dirancang untuk untuk memproduksi kertas tulis cetak 60 gsm bahan baku virgin digunakan untuk memproduksi kertas tulis cetak 45 gsm berbahan baku virgin maupun kertas daur-ulang berdasarkan permintaan pasar. Dalam penelitian ini diamati kajian kinerja pengering silinder mesin kertas saat pengeringan produk kertas tulis cetak 45 gsm dan simulasi kemampuan pengeringan pengering silinder tersebut sampai batas kecepatan rancangan mesin kertas. Hasil diharapkan dapat memberikan kontribusi terhadap efisiensi energi, sehingga langkah antisipasi terhadap kemungkinan penurunan kontribusi keuntungan dapat dilakukan.
\end{abstract}

Kata kunci: pengering silinder, kecepatan rancangan, efisiensi energi, kontribusi keuntungan

\section{PENDAHULUAN}

Dalam dunia industri peluang dan kondisi pasar yang fluktuatif merupakan tantangan. Produsen diharuskan mampu mensiasati berbagai kondisi yang ada dengan meminimalkan modal investasi yang diperlukan untuk memodifikasi peralatan yang ada jika ingin dapat melayani pasar. Fluktuasi kecenderungan produksi pulp dan kertas serta tisu, perusakan lingkungan yang disebabkan oleh industri berbahan baku kayu hasil hutan mengharuskan produsen selektif dalam menentukan langkah bisnisnya. Permintaan kertas tulis cetak secara global cukup 
baik, ditunjang oleh permintaan pasar yang tumbuh di negara berkembang (CAGR 2,2\% dan $3,1 \%$ ) untuk kertas tulis cetak tanpa salut maupun dengan salut (Jako Poyry, 2012).

Biaya produksi tinggi umumnya dikarenakan tidak adanya efisiensi dalam proses produksi, seperti rasio hari operasi efektif terhadap hari operasi produksi masih rendah (HOE/HOP rendah). Rugi waktu tinggi akan berdampak langsung ke pemakaian bahan baku dan bahan penolong tinggi. Dampak langsungnya adalah konsumsi energi per satuan produk tinggi.

Konsumsi energi beberapa mesin kertas sangat bervariasi tergantung dari banyak faktor. Faktor kelancaran mesin sangat dipengaruhi hasil pengembangan serat. Sifat kekuatan lembaran kertas basah yang dihasilkan menentukan tingkat konsumsi energi per satuan berat kertas, baik energi listrik (kWh/ton kertas) maupun energi panas uap (GJ/ton kertas). Dalam industri pulp dan kertas, praktek terbaik dunia (world best practice) untuk konsumsi energi selalu didasarkan pada bahan baku yang berasal dari kayu, sehingga nilai ini tidak dapat diterapkan untuk produk yang berbahan baku non kayu. Sumber informasi tentang praktek terbaik industri kertas berbahan baku non kayu sangat langka (Worrell dkk., 2008).

Konsumsi energi mesin kertas secara garis besar tergantung dari kualitas pulp yang digunakan dan kualitas produk/spesifikasi kertas yang diproduksi. Karakteristik pulp dan jenis kertas sangat beragam, sehingga mempengaruhi tingkat konsumsi energi yang ada (Weineisen, 2000). Dengan demikian dalam membandingkan konsumsi energi proses produksi kertas harus dilihat secara menyeluruh terkait bahan baku yang digunakan, komposisi dan perlakuan terhadap serat selama pengembangan serat dan konsolidasi serat dilakukan. Data dalam Tabel 1 dibawah adalah hasil pengamatan pada industri pulp dan kertas di Negara Canada.

Pengeringan merupakan salah satu bagian di mesin kertas yang mengkonsumsi energi cukup tinggi. Banyaknya air bebas dan air yang terikat secara molekuler kepada struktur serat akan menentukan perilaku pengurangan kadar air secara mekanis maupun termal (Weineisen, 2000). Parameter utama yang menentukan struktur kertas yang berpori adalah porositas, luas permukaan spesifik, ukuran pori, distribusi ukuran pori, dan permeabilitas (Weineisen, 2000). Sedangkan parameter yang menentukan transfer massa air dalam struktur kertas adalah daya ikat serat terhadap air, dinyatakan sebagai water retention value (WRV) yang diakibatkan oleh pengembangan serat selama proses refining (Wikanaji, 2003). Kertas adalah media berpori yang sangat komplek, tersusun dari campuran serat dan bahan pengisi. Struktur kertas dipengaruhi oleh bahan baku yang digunakan seperti, spesies kayu dan proses pembuatan dan pemutihan pulp yang digunakan, teknik pembentukan lembaran kertas yang digunakan, serta jenis dan banyaknya bahan pengisi yang digunakan. Ukuran dan distribusi ukuran lubang (porositas) kertas bervariasi dari celah antar serat yang relatif besar sampai ukuran molekuler. Dengan demikian porositas kertas juga berpengaruh terhadap proses pengeringan (Keranen, 2011). Pemilihan bahan baku dan derajat giling yang digunakan sangat berpengaruh terhadap karakteristik proses pengeringan dan sifat fisik kertas yang dihasilkan (Zhang dkk., 2005).

Secara skematik faktor yang mempengaruhi pengeringan kertas dapat digambarkan pada Gambar 1 (Keranen, 2011). Penelitian ini bertujuan untuk mengevaluasi kinerja bagian

Tabel 1. Ringkasan Praktek Terbaik Dunia Pemakaian Energi Mesin Kertas

\begin{tabular}{clcccccc}
\hline \multirow{2}{*}{$\begin{array}{c}\text { Bahan } \\
\text { Baku }\end{array}$} & \multirow{2}{*}{ Produk } & \multirow{2}{*}{ Proses } & \multicolumn{2}{c}{$\begin{array}{c}\text { Pemakaian bahan } \\
\text { bakar untuk steam }\end{array}$} & $\begin{array}{c}\text { Pemakaian } \\
\text { listrik }\end{array}$ & \multicolumn{2}{c}{ Total } \\
\cline { 3 - 8 } & & & GJ/Adt & $\mathrm{kgce} / \mathrm{ADt}$ & $\mathrm{kWh} / \mathrm{ADt}$ & GJ/Adt & $\mathrm{kgce} / \mathrm{ADt}$ \\
\hline \multirow{6}{*}{ Pulp } & Uncoated Fine (wood free) & Paper Machine & 6,7 & 229 & 640 & 9,0 & 307 \\
& Uncoated Fine (wood free) & Paper Machine & 7,5 & 256 & 810 & 10,4 & 355 \\
& Newsprint & Paper Machine & 5,1 & 174 & 570 & 7,2 & 244 \\
& Board & Paper Machine & 6,7 & 229 & 800 & 9,6 & 327 \\
& Kraftliner & Paper Machine & 5,9 & 201 & 535 & 7,8 & 267 \\
& Tissue & Paper Machine & 6,9 & 235 & 1000 & 10.5 & 358 \\
\hline
\end{tabular}

(Sumber: Worrel dkk., 2008)

Keterangan: kgce $=$ kilogram coal equivalent. 


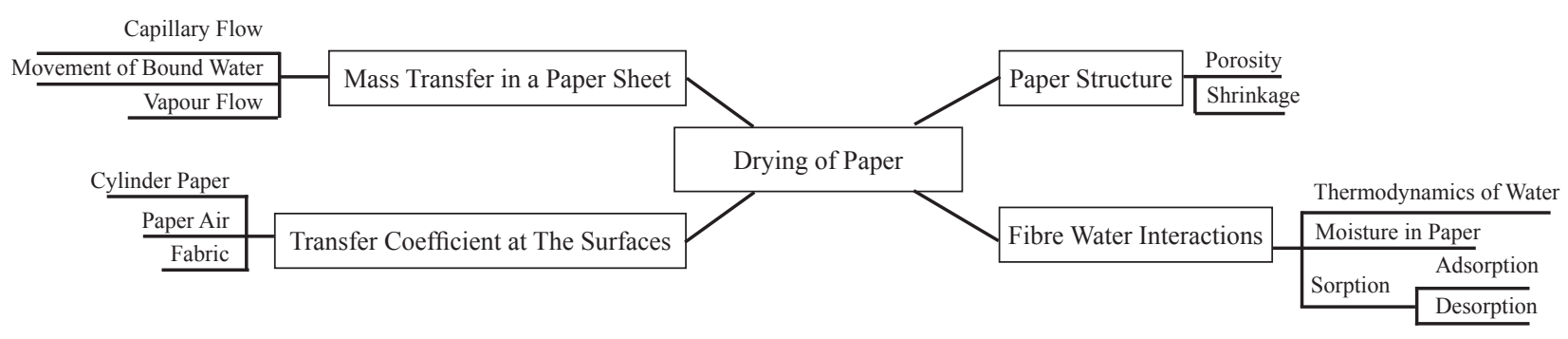

(Sumber: Keranen, 2011)

Gambar 1. Faktor Berpengaruh terhadap Proses Pengeringan Kertas.

pengeringan (dryer section) pada mesin kertas yang memproduksi kertas dengan gramatur rendah.

\section{BAHAN DAN METODE}

Penelitian ini difokuskan pada upaya mendapatkan potensi kemampuan dryer untuk meningkatkan produktivitas mesin kertas. Pengamatan dilakukan pada Mesin Kertas 5 di salah satu pabrik kertas di Jawa Timur saat mengerjakan kertas tulis cetak gramatur rendah 45 gsm. Pengamatan suhu di tiap silinder pengering dilakukan dengan thermo hunter RayTech. Data operasional yang dapat diambil adalah laju produksi (throughput), tekanan uap pada masing-masing kelompok silinder, kadar air lembar kertas basah keluar unit pengepresan dan kadar air produk kertas. Saat terjadi putus lembaran dilakukan pengambilan sampel kertas untuk dilakukan pemeriksaan silang kadar air. Perubahan kadar kering kertas saat mengalami proses pengeringan mulai titik masuk pengering sampai reel dihitung berdasar data pengamatan yang berhubungan dengan operasional proses produksi. Dari data yang ada kemudian dilakukan simulasi kemampuan pengering saat kecepatan mesin kertas ditingkatkan. Perlakuan refining dan pengepresan menjadi batasan masalah sehingga kadar air kertas basah masuk pengering dianggap sama $62 \%$ dan kadar air produk kertas $6 \%$ adalah tetap.

Data penunjang: Bahan baku kertas adalah LBKP $100 \%$, bahan pengisi yang diumpankan adalah $G C C$ dalam bentuk lumpur dengan kadar padatan $65 \%$. Lebar kertas di reel $6,3 \mathrm{~m}$, lebar kertas basah 6,5 $\mathrm{m}$ dihitung dari lebar wire $6,9 \mathrm{~m}$ dikurangi trim deckle. Kecepatan mesin $600 \mathrm{mpm}$ dengan kecepatan terdisain $800 \mathrm{mpm}$ dan balancing speed $900 \mathrm{mpm}$. Laju produksi mesin kertas 10,2 ton/jam. Konsumsi listrik $940 \mathrm{kWh} /$ ton dan uap 2,8 ton uap/ton kertas $(\approx 6 \mathrm{GJ} / \mathrm{AD}$ ton $)$ sesuai prosedur operasi standar. Kadar air kertas hasil pemeriksaan 3,8-4,0\%. Jarak tarikan antar pengering silinder $1,5 \mathrm{~m}$ dan humiditas udara di dalam hood 0,21 kg air/kg udara kering. Data sekunder dari pustaka: massa jenis serat selulosa $1500 \mathrm{~kg} / \mathrm{m}^{3}$, kapasitas panas spesifik selulosa $0,37 \mathrm{kal} / \mathrm{g}^{\circ} \mathrm{C}$, kapasitas panas spesifik serat $L B K P$ dianggap sama dengan selulosa $0,37 \mathrm{kal} / \mathrm{g}^{\circ} \mathrm{C}$ dan data sifat fisik udara.

Pada pengeringan kertas di mesin kertas air akan teruapkan. Laju penguapan dari lembar kertas basah ke udara didalam dryerhood digambarkan dengan persamaan Stefan (Persamaan 2) (Karlsson, 2000).

$$
\frac{m_{e v}}{A}=\frac{\beta \cdot p_{t o t}}{R \cdot T} \ln \left(\frac{p_{t o t}-p_{v a}}{p_{t o t}-p_{v p 0}}\right)
$$

Dengan $\beta$ koefisien transfer massa, $p_{\text {tot }}$ tekanan total, $p_{v p 0}$ tekanan parsial uap di permukaan kertas, $\mathrm{p}_{\mathrm{va}}$ tekanan parsial uap didalam dryerhood, $A$ luas permukaan kertas, $R$ konstanta gas dan $T$ suhu. Pada kondisi aliran turbulen (kondisi umum di dryer hood), persamaan (2) dapat disederhanakan menjadi Persamaan 3 (Berg, 1999).

$$
\frac{m_{e v}}{A}=\frac{\beta}{R . T}\left(p_{v p 0}-p_{v a}\right)
$$

Neraca panas dihitung dengan menggunakan Persamaan 4. Dengan $m, c, T$ dan $h$ adalah massa, kapasitas panas, suhu dan entalpi; sementara 


$$
\begin{aligned}
& \left(m_{p} \cdot c_{p}+m_{w} \cdot c_{w}\right)\left(T_{i}-T_{r e f}\right)+m_{s} \cdot h_{\text {vap }}+m_{u} \cdot c_{u}\left(T_{i u}-T_{r e f}\right)=m_{c} \cdot h_{\text {liq }}+\left(m_{p} \cdot c_{p}+\right. \\
& \left.m_{w} \cdot c_{w}\right)\left(T_{o}-T_{r e f}\right)+m_{u} \cdot c_{u}\left(T_{o u}-T_{\text {ref }}\right)
\end{aligned}
$$

indek $p, w, s, u, v a p$, liq, $i$, ou dan ref menunjukkan kertas, air, uap, udara, fasa uap, fasa air, kondisi masuk dan keluar, serta referensi.

\section{HASIL DAN PEMBAHASAN}

Konfigurasi pengering silinder ditunjukkan pada Gambar 2, dengan demikian tekanan uap pada masing-masing kelompok silinder dapat diatur menyesuaikan kondisi operasional.

Dari hasil perhitungan diperoleh neraca massa keseluruhan sebagaimana pada Gambar 2. Hasil neraca massa diatas digunakan untuk dasar perhitungan kadar kering kertas secara bertahap saat melewati pengering silinder. Untuk simulasi peningkatan kapasitas mesin dilakukan perhitungan serupa.

Hasil simulasi pengeringan di bagian pengering untuk kecepatan 600 dan $800 \mathrm{mpm}$ disajikan pada Gambar 3 dan Gambar 4. Gambar 3 disajikan kinerja bagian pengering mesin kertas saat produksi HVS $45 \mathrm{gsm}$. Terlihat bahwa lembaran kertas sudah kering (kadar air 6\%) saat kertas melewati silinder pengering nomor 36 . Pengering nomor 1 sampai 22 melaksanakan pemanasan awal menuju ke titik optimal, pengering nomor $23-41$, kemampuan optimal menguapkan air $754 \mathrm{~kg} / \mathrm{jam}$ sedangkan pengering nomor 42 berfungsi sebagai pendingin sehingga laju penguapan air turun menjadi $509 \mathrm{~kg} / \mathrm{jam}$. Untuk itu pengering nomor 37 sampai dengan nomor 41 tidak berfungsi untuk proses pengeringan. Energi panas dari uap terbuang karena tidak dimanfaatkan untuk pengeringan, bahkan kertas menjadi kering berlebih. Kadar air kertas yang teramati 3,8\% berasal dari adsorpsi uap air dari udara sekitar sesudah keluar dari mesin kertas.

Pada Gambar 3 juga nampak bahwa secara bertahap mulai silinder pengering nomor 7 laju penguapan air naik dengan pesat mulai $>50 \mathrm{~kg} / \mathrm{jam}$ menuju $>746 \mathrm{~kg} / \mathrm{jam}$ saat mencapai silinder pengering nomor 22 dan seterusnya konstan 754 $\mathrm{kg} / \mathrm{jam}$ sampai silinder pengering nomor 41 dan $509 \mathrm{~kg} / \mathrm{jam}$ pada pengering nomor 42 (silinder pendingin). Pada kondisi ini tingkat pemakaian energi listrik sebesar $940 \mathrm{kWh} / \mathrm{ADt}$ dan uap 2,8 t/t $(\approx 6 \mathrm{GJ} / \mathrm{ADt}$ ), tingkat konsumsi yang masih boros.

Jika dianggap kondisi ideal dapat dicapai yaitu kelancaran mesin kertas identik dan throughput diasumsikan proporsional terhadap kecepatan mesin, maka perolehan produksi kertas dapat mencapai 13,6 ton/produksi kertas atau naik 4,3 ton/jam dari perolehan sebelumnya 10,2 ton/jam, dan tingkat konsumsi energi adalah tetap. Pada proses ini, konsumsi listrik adalah $705 \mathrm{kWh} / \mathrm{t}$ dan konsumsi uap 2,1 ton/ton kertas $(\approx 4,5 \mathrm{GJ} / \mathrm{ADt})$, merupakan tingkat konsumsi energi yang effisien. Nilai tersebut setara dengan hasil evaluasi oleh Riyanto (2007) menyatakan bahwa konsumsi steam di mesin kertas pabrik kertas dengan gramatur rendah $(<60$ gsm) adalah 1,8 t/ton kertas (4 GJ/ADt)
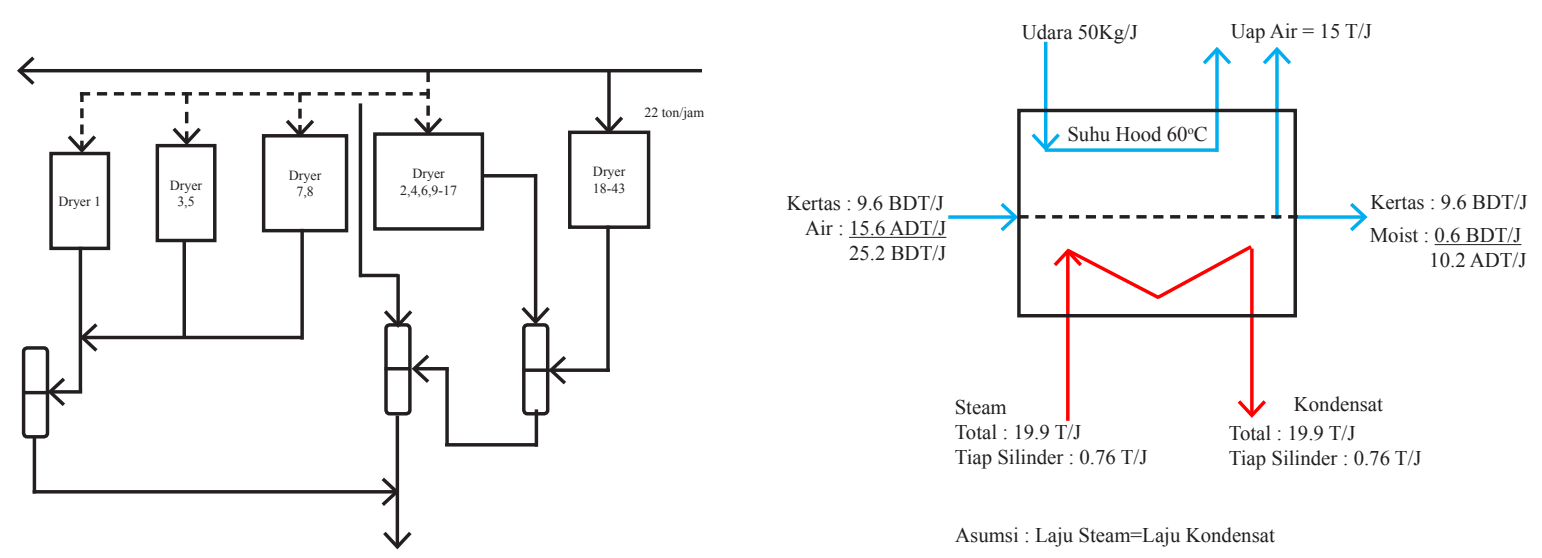

Gambar 2. Neraca Massa dan Konfigurasi Jalur Uap di Bagian Pengering 


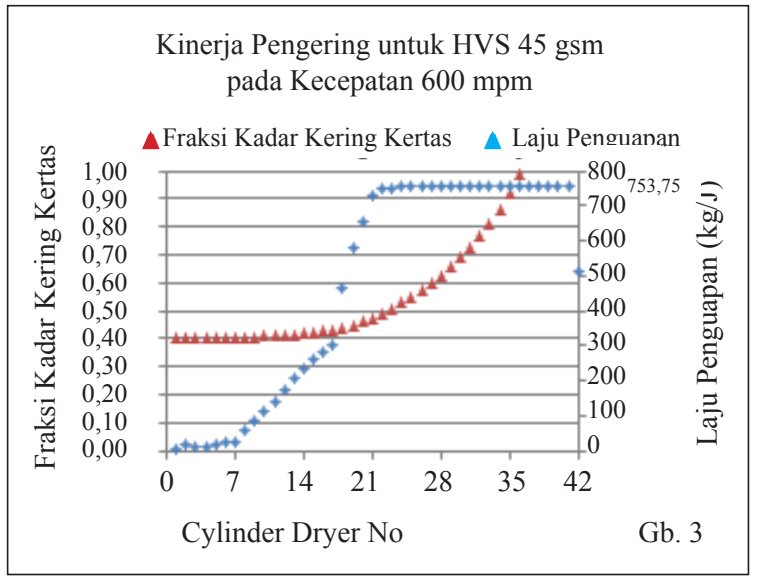

Gambar 3. Laju Penguapan dan Kadar Kering Kertas pada Kecepatan Mesin 600 mpm (Kadar Air 3,8-4,0\%).

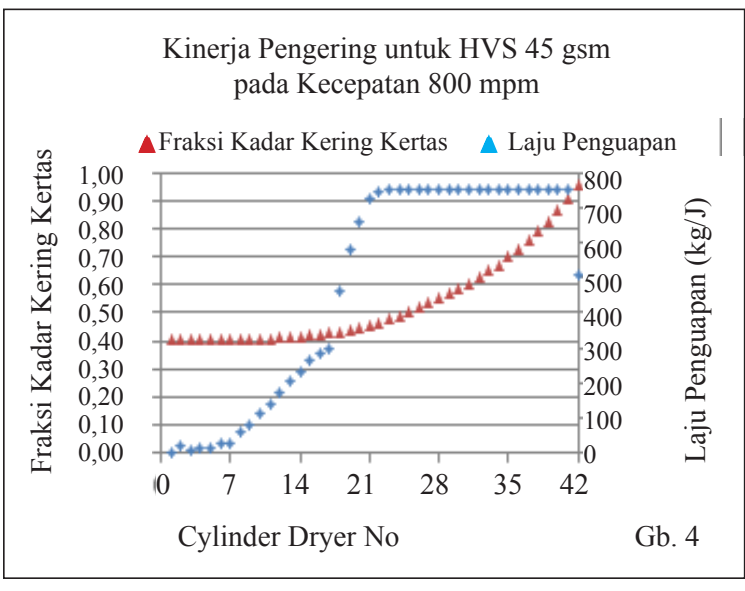

Gambar 4. Laju Penguapan dan Kadar Kering Kertas pada Kecepatan Mesin $800 \mathrm{mpm}$ (Simulasi dengan Target Kadar Air Maksimal 6.0 \%).

dan konsumsi listrik $550-600 \mathrm{kWh} /$ ton kertas. Pabrik kertas tersebut menggunakan bahan baku NBKP Keinleith $6-10 \%$, LBKP Acacia dan MHW 70\%, broke $10 \%$, dan kadar abu $20-25 \%$, memiliki maksimal rugi waktu putus lembaran 10 menit/hari dengan total pemeliharaan terencana dan tidak terencana 25 jam per bulan. Sedangkan di Kanada, konsumsi uap di mesin kertas berkisar antara 5,1-7,5 GJ/ADt.

Gambar 4 menunjukkan hasil simulasi pengeringan di mesin kertas dengan asumsi kinerja mesin secara keseluruhan sama. Pengering masih mampu untuk mengeringkan kertas HVS 45 gsm pada saat kecepatan mesin dinaikkan menjadi $800 \mathrm{mpm}$. Pada pengering nomor 41 kertas sudah kering dengan kadar air 9\% dan saat melewati pendingin (pengering nomor 42) kadar air mencapai 6\% (sesuai target). Sebuah potensi sangat besar yang dapat diperoleh dengan memanfaatkan kapasitas pengering, apalagi jika optimasi pengurangan kadar air di bagian pengepresan juga dapat dilakukan.

Pada tingkat kelancaran mesin sama dan biaya energi sama, mesin kertas yang semula hanya mampu memproduksi kertas 10,2 t/jam meningkat menjadi 13,6 t/jam (ada peningkatan produktivitas 33,3\%). Artinya ada penurunan biaya energi per ton produk dari $\mathrm{Rp} \mathrm{x},-/ 10,2$ ton menjadi $\mathrm{Rp} \mathrm{x},-/ 13,6$ ton atau setara penurunan biaya energi $25 \%$.

\section{KESIMPULAN}

Kertas hasil produksi terlalu kering dengan kadar kering melebihi target. Ditinjau dari pemanfaatan kapasitas pengering, operasional mesin kertas belum efisien. Kapasitas pengering yang belum termanfaatkan masih sangat besar dan ada potensi menurunkan biaya energi per satuan produk sekitar 25\%. Kendala operasional lain terkait rendahnya produktivitas perlu dikaji lebih jauh terutama untuk meningkatkan pendapatan perusahaan.

\section{SARAN}

Perlu dilakukan penelitian lebih mendalam karena potensi kapasitas mesin kertas tidak hanya ditentukan oleh kapasitas drier, tetapi lost time yang disebabkan paper break dan kerusakan mesin juga mempengaruhi produktivitas secara menyeluruh. Dampak optimasi pengurangan kadar air di bagian pengepresan terhadap kemampuan pencapaian kadar kering pada target throughput juga perlu diperhitungkan.

\section{DAFTAR PUSTAKA}

Berg, C.G. 1999. "Heat and mass transfer in turbulent moist air drying processes: experimental and theoretical work". Doctoral Thesis. Åbo Akademis Förlag.

Worrell, E., Price, L., Neelis, M., Galitsky, C., Zhou, N. 2008. World Best Practice Energy Intensity Values for Selected Industrial Sectors. Environmental Energy Technologies Division. Ernest Orlando Lawrence Berkeley National Laboratory. 
Weineisen, Henrik. 2003. Through Drying of Paper - A Literature Review Arbetsrapport $S G C$ A40. Department of Chemical Engineering - Lund Institute of Technology, Sweden.

Jaakko Poyry, 2012, Market Analysis - Report, Department for International Development.

Karlsson. M., 2000. Papermaking Science and Technology: Part 2, Drying. Papermaking. Book 9. Fapet. ISBN 9525216004

Keranen, J.. 2011. Increasing the Drying Efficiency of Cylinder Drying. Academic Dissertation For the Degree of Doctor of Philosophy, Department of Physics University of Jyväskylä, Finland.
Riyanto, S., 2007. Laporan Studi Banding ke Pabrik Kertas Tjiwi Kimia. Probolinggo.

Wikanaji, D., 2003. The Combination of LC and HC Refining Process to Achieve Fiber Development. UPM Kymmene, Finland.

Zhang, G., Janne, K., Kaarlo, N. 2005. Effect of drying condition on the mechanical properties of paper. Paperi ja Puu / Pulp and Timber. Vol. 86 No: 3, $164-168$. 